\title{
A Low-Density Graphite-Polymer Composite as a Bipolar Plate for Proton Exchange Membrane Fuel Cells
}

\author{
S. R. Dhakate, S. Sharma and R. B. Mathur \\ Physics and Engineering of Carbon, Materials Physics and Engineering Division, CSIR-National Physical Laboratory, Dr. K. S. \\ Krishnan Marg, New Delhi 110 012, India
}

\section{Article Info}

Received 24 July 2012

Accepted 17 December 2012

*Corresponding Author

E-mail: dhakate@mail.nplindia.org Tel: +0911145608257

\section{Open Access}

DOI: http://dx.doi.org/

10.5714/CL.2012.14.1.040

This is an Open Access article distributed under the terms of the Creative Commons Attribution Non-Commercial License (http://creativecommons.org/licenses/ by-nc/3.0/) which permits unrestricted non-commercial use, distribution, and reproduction in any medium, provided the original work is properly cited.

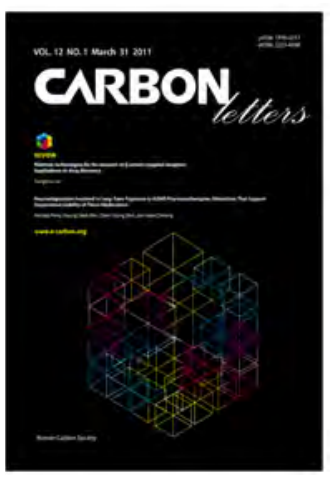

http://carbonlett.org

pISSN: 1976-4251

elSSN: 2233-4998

Copyright $\odot$ Korean Carbon Society

\begin{abstract}
The bipolar plate is the most important and most costly component of proton exchange membrane fuel cells. The development of a suitable low density bipolar plate is scientifically and technically challenging due to the need to maintain high electrical conductivity and mechanical properties. Here, bipolar plates were developed from different particle sizes of natural and expanded graphite with phenolic resin as a polymeric matrix. It was observed that the particle size of the reinforcement significantly influences the mechanical and electrical properties of a composite bipolar plate. The composite bipolar plate based on expanded graphite gives the desired mechanical and electrical properties as per the US Department of Energy target, with a bulk density of $1.55 \mathrm{~g} . \mathrm{cm}^{-3}$ as compared to that of $\sim 1.87 \mathrm{~g} . \mathrm{cm}^{-3}$ for a composite plate based on natural graphite (NG). Although the bulk density of the expandedgraphite-based composite plate is $\sim 20 \%$ less than that of the NG-based plate, the I-V performance of the expanded graphite plate is superior to that of the NG plate as a consequence of the higher conductivity. The expanded graphite plate can thus be used as an electromagnetic interference shielding material.
\end{abstract}

Key words: electrical conductivity, mechanical properties, bipolar plate, proton exchange membrane fuel cell

\section{Introduction}

A fuel cell is an electrochemical device that convert the chemical energy directly in to electrical energy, without an often messy and relatively inefficient combustion step. Due to its potential to reduce the environmental impact and geopolitical consequence of the use of fossil fuels, it emerged as tantalizing alternatives to combustion engines. Many types of fuel cells have been demonstrated so far, polymer electrolyte membrane (PEM) fuel cell is considered viable for personal transportation application due to its high power density, low operating temperature, quick start-up time and virtual zero emissions [1,2]. A typical PEM fuel cell consists of an anode backing, membrane electrode assembly and cathode backing sandwiched between two bipolar plates. Within the fuel cell stack, bipolar plate connects the cells physically, electrically and thermally. The commercialization of PEM fuel cell for automotive and stationary applications is required to reduce cost, weight and volume of fuel cell stack components. The major cost and weight of fuel cell stack come from bipolar plate, cost accounts $45-50 \%$ and weight $70 \%$ of fuel cell stack [3]. The most commonly used bipolar plates are made from graphite and metal. The advantages of graphite plate are excellent corrosion resistance, low bulk density and electrical resistivity. On the other hand, the disadvantages are difficulties in machining, and its brittleness [4-6].

There are plenty of studies reported in literature to overcome the disadvantages of graphite based bipolar plates and developed graphite -polymer composite bipolar plates with graphite powder, in these studies systematic approach is not adapted to develop compos- 
ite bipolar plates. Therefore, in this study authors have tried to develop low density composite bipolar plate by using different particle size of natural graphite (NG) or expanded graphite (EG) with combination of other fillers i.e., carbon black and chopped carbon fibers, to achieve the desired properties as per US Department of Energy (DOE) target (in-plane conductivity $>100 \mathrm{~S} /$ $\mathrm{cm}$, through-plane conductivity $>20 \mathrm{~S} / \mathrm{cm}$, flexural strength $>25$ $\mathrm{MPa}$, thermal conductivity $>20 \mathrm{~W} / \mathrm{m} . \mathrm{K}$ ) of bipolar plate.

\section{Experimental}

In this study, two types of conducting fillers were used as major reinforcements, i.e., NG of different particle sizes and EG synthesized from different particle sizes of NG [7]. Carbon black and PAN-based T-300 carbon fiber in a chopped form (diameter $7 \mu \mathrm{m}, 2-3 \mathrm{~mm}$ in length) were also used as additional filler materials. Novolac-type phenolic resin-9624 was used as matrix binder. It was procured from Pheno Organic Limited, New Delhi, India.

Composite bipolar plates were developed from different particle sizes of NG and EG with Novolac phenolic resin $60 \mathrm{~mm}$ $\times 20 \mathrm{~mm} \times 4 \mathrm{~mm}$ in size by a compression molding technique [8]. In this study, three types of composite series were prepared. In the first series, composite plates were developed from different particle sizes of NG with a fixed content of constituent fillers of carbon black (10 wt\%), carbon fiber polyacrylonitrile-based $\mathrm{T}-300(5 \mathrm{wt} \%)$ and Novolac phenolic (30 wt \%) resin as a polymer matrix. In another series, EG-based composite plates were developed from different particle sizes of EG, EG content at $50 \mathrm{wt} \%$ with an addition of $10 \mathrm{wt} \% \mathrm{NG}$ of the same size, and polymeric phenolic resin 40 at $\mathrm{wt} \%$ in all samples. The surface area of the EG is high as compared to the NG; thus, a higher amount of polymeric resin was used. In another set of experiments, EG composites were developed from EG with a particle size of $150 \mu \mathrm{m}$ with different percentages of chopped carbon fibers and fiber content varying from 1 to $5 \mathrm{wt} \%$. All of the composite plates were coded with the particle sizes shown in Table 1. All composite plates were characterized for their electrical conductivity (EC), shore hardness, bending strength, air permeability and I-V performance, as reported in earlier studies [9]. The thermal conductivity levels of the composite plates were measured by a laser flash technique with a xenon laser as the source in a Thermo Flash Line 2003 instrument (Anter Corporation, Pittsburgh, PA, USA).

The electromagnetic interference (EMI) shielding effectiveness was measured in terms of the waveguide using a vector network analyzer (VNA, E8263B, Agilent Technologies). Rectangular samples $2.70-2.75 \mathrm{~mm}$ thick were placed inside the cavity of a sample holder which matches the internal dimensions of the $x$-band (8.2-12.4 GHz) wave guide. The sample holder was placed between the flanges of the waveguide connected between the two ports of the VNA.

\section{Results and Discussion}

Fig. 1 shows scanning electron microscope (SEM) micrographs of the NG and EG. Fig. 1a shows NG particles of different sizes and shapes. Fig. 1b shows a SEM micrograph of an EG
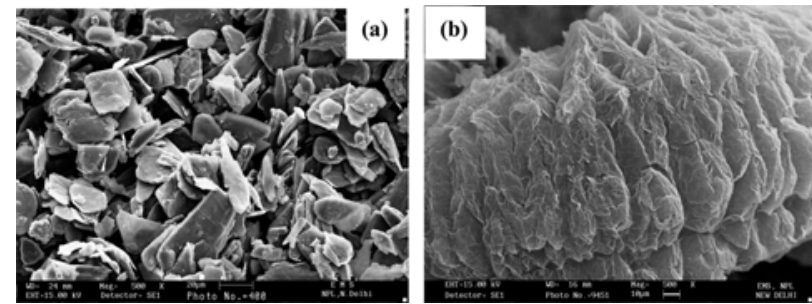

Fig. 1. Scanning electron microscope micrographs: (a) natural graphite, (b) expanded graphite at higher magnification.

particle with a vermiform shape and a loose and porous structure [7] and with a high surface area.

For use in a PEM fuel cell stack, a bipolar plate should have a low density, high EC and adequate mechanical properties. Table 1 shows the properties of a commercially available bipolar plate [10-17] compared to the plate developed in the present work. These previously reported bipolar plates do not satisfy all of the properties necessary for a bipolar plate.

Table 1 shows the mechanical and electrical properties of different types of bipolar plates made from different sizes of $\mathrm{NG}$ and EG particles in the present study. The bulk density of the NG-based plates varies from 1.85 to $1.92 \mathrm{~g} . \mathrm{cm}^{-3}$, while the density of the EG-based composite plate is in the range of 1.57-1.61 g. $\mathrm{cm}^{-3}$. It was found that with an increase in the particle size of the NG, the bulk density of the composite plate increases. This increase is in accordance with particle size gradation theory and is in fair agreement with accumulation theory. With an increase in the particle size of graphite, larger particles are not closely accommodated in the same volume as compared to smaller particles. This leads to fewer contact boundaries in the case of a composite based on larger particles in the same volume as compared to composite plates based on a smaller particle size. As a result, a lower shore hardness was noted for the composite plates based on larger particles as compared to those based on smaller particles. On the other hand, the shore hardness of the EG-based plates is $10-15 \%$ less than that of the NG-based plates. A high level of in-plane EC is an essential feature of proton exchange membrane fuel cell (PEMFC) bipolar plates. A percolating conducting path is necessary to achieve a high EC [18]. The EC (in-plane) of composite plate increases with an increase in the NG particle size (Table 1). In a composite based on a larger particle size, the conductivity is controlled by the number of contact boundaries between NG particles; larger NG particles lead to fewer contact boundaries. As a result, a higher percolating conducting path for electrons exists. On the other hand, the value of the through-plane conductivity becomes quite less compared to the in-plane conductivity, with maximum values of $\sim 50 \mathrm{~S} / \mathrm{cm}$ for a composite based on a particle size of 50 to 75 microns. However, in the case of an EG-based composite plate, the trend of the conductivity value is identical as that of NG-based plates. However, the ultimate value of the in plane $\mathrm{EC}$ is higher $(800 \mathrm{~S} / \mathrm{cm})$ for a composite plate based on larger particles $(500 \mu \mathrm{m})$. Nonetheless, the through-plane EC is $50 \mathrm{~S}$ / $\mathrm{cm}$ for composite plates based on smaller particles and $60 \mathrm{~S} / \mathrm{cm}$ for composite plates based on larger particles. Upon an addition of carbon fibers to EG-based composite plates, both the in-plane and through-plane EC deceases due to the much lower conduc- 
Table 1. Electrical and mechanical properties of NG- and EG-based composite bipolar plates

\begin{tabular}{|c|c|c|c|c|c|c|c|}
\hline \multirow[t]{2}{*}{$\begin{array}{l}\text { Composite } \\
\text { bipolar plate }\end{array}$} & \multirow[t]{2}{*}{ Density $\left(\mathrm{g} \mathrm{cm}^{-3}\right)$} & \multirow[t]{2}{*}{$\begin{array}{c}\text { Shore } \\
\text { hardness }\end{array}$} & \multicolumn{2}{|c|}{$\mathrm{EC}(\mathrm{S} / \mathrm{cm})$} & \multirow[t]{2}{*}{$\begin{array}{c}\mathrm{TC} \\
\mathrm{W} / \mathrm{m} \cdot \mathrm{K}\end{array}$} & \multirow[t]{2}{*}{$\mathrm{BS}(\mathrm{MPa})$} & \multirow[t]{2}{*}{ Modulus (GPa) } \\
\hline & & & In-plane & Through-plane & & & \\
\hline DOE target & - & - & $>100$ & $>10$ & 20 & 50 & - \\
\hline Ref. [10] & 1.82 & & & & & 38.5 & 9.0 \\
\hline Ref. [11] & 1.38 & & 129 & & & 31.8 & \\
\hline Ref. [12] & 1.85 & & 250 & & & 50 & \\
\hline Ref. [13] & & & 100 & 50 & & 60 & \\
\hline Ref. [14] & & & 100 & 20 & & 40 & \\
\hline Ref. [15] & & & 119 & & & 36.2 & \\
\hline Ref. [16] & & & 171 & & & 60.2 & \\
\hline Ref. [17] & & & 120 & & & 38 & \\
\hline
\end{tabular}

Present work

Composition: $\mathrm{NG}$ particle size ( $\mathrm{NG} w \mathrm{t} \%+$ carbon black $\mathrm{wt} \%+$ carbon fiber $\mathrm{wt} \%+$ resin $\mathrm{wt} \%$ )

\begin{tabular}{|c|c|c|c|c|c|c|c|}
\hline NG-30 $(55+10+5+30)$ & 1.85 & 67 & 155 & 45 & 25 & 75 & 18 \\
\hline NG-38 $(55+10+5+30)$ & 1.87 & 67 & 180 & 47 & - & 73 & 16.5 \\
\hline NG-50 $(55+10+5+30)$ & 1.89 & 65 & 237 & 50 & 31 & 70 & 15 \\
\hline NG-75 $(55+10+5+30)$ & 1.9 & 62 & 276 & 50 & - & 65 & 14 \\
\hline NG-150 (55+10+5+30) & 1.92 & 56 & 300 & 48 & 60 & 60 & 12 \\
\hline \multicolumn{8}{|c|}{ Composition: EG particle size (EG wt $\%+10 \mathrm{wt} \% \mathrm{NG}+$ resin $\mathrm{wt} \%)$} \\
\hline EG-30 $(50+10+40)$ & 1.58 & 60 & 75 & 50 & 22 & 70 & 14 \\
\hline EG-38 $(50+10+40)$ & 1.58 & 58 & 85 & 55 & - & 68 & 12 \\
\hline EG-50 $(50+10+40)$ & 1.58 & 55 & 153 & 57 & - & 63 & 11 \\
\hline EG-75 $(50+10+40)$ & 1.58 & 53 & 208 & 60 & - & 60 & 11 \\
\hline EG-150 $(50+10+40)$ & 1.58 & 50 & 357 & 60 & 23 & 49 & 9 \\
\hline EG-300 $(50+10+40)$ & 1.58 & 45 & 700 & 58 & - & 44 & 7 \\
\hline EG-500 $(50+10+40)$ & 1.58 & 41 & 800 & 50 & 45 & 40 & 5 \\
\hline \multicolumn{8}{|c|}{ Composition: EG particle size (EG wt $\%+$ carbon fiber $w t \%+$ Resin $w t \%)$} \\
\hline EG150 $(59+1+40)$ & 1.59 & 52 & 210 & 58 & - & 50 & 11 \\
\hline EG150 $(58+2+40)$ & 1.59 & 54 & 190 & 55 & - & 54 & 12 \\
\hline EG150 $(57+3+40)$ & 1.60 & 57 & 175 & 50 & 20 & 57 & 13 \\
\hline EG150 $(56+4+40)$ & 1.60 & 60 & 165 & 50 & - & 61 & 13 \\
\hline EG150 $(55+5+40)$ & 1.60 & 62 & 152 & 47 & - & 67 & 14 \\
\hline
\end{tabular}

NG: natural graphite, EG: expanded graphite, EC: full words, TC: thermal conductivity, BS, bending strength, DOE: US Department of Energy.

tivity of carbon fibers as compared to EG. This clearly shows that the smaller particles are oriented in all three directions as compared to larger particles, which are preferably oriented in the $\mathrm{x}-\mathrm{y}$ direction due to their size.

In addition, the higher value of the through-plane EC of the G-based plate is due to the lower modulus (comparatively more flexible than an NG plate), which can help to reduce the contact resistance.

The thermal conductivity is also a requisite property of a bipolar plate for heat dissipation during the functioning of the fuel cell stack when it is operated above a temperature of $70^{\circ} \mathrm{C}$. The thermal conductivity values of composite plates with larger and 


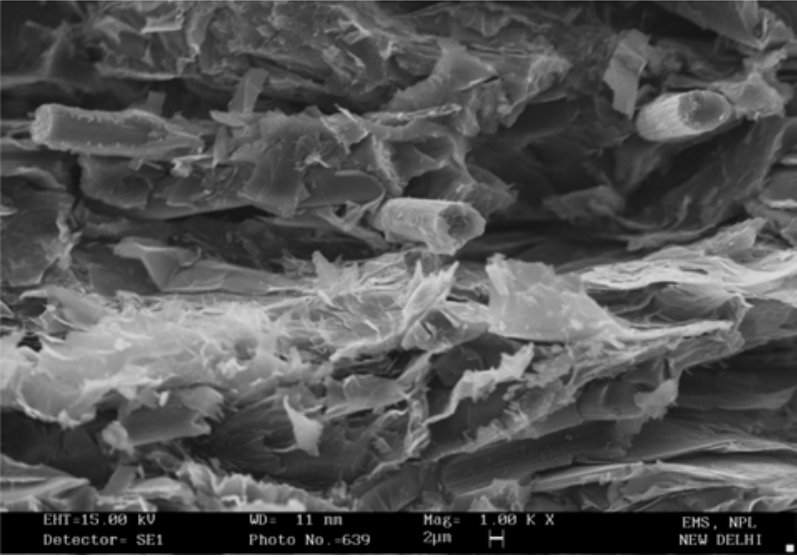

Fig. 2. Scanning electron microscope micrograph of an expanded graphite-based composite with carbon fiber.

smaller NG particles are 65 and $26 \mathrm{~W} \cdot \mathrm{m}^{-1} \mathrm{~K}^{-1}$, respectively, while the EG is 45 and $22 \mathrm{w} / \mathrm{m} . \mathrm{K}$ for plates based on larger and smaller particles, respectively (Table 1). The higher value of conductivity is due to the fewer contact boundaries in the plate based on a particle size of $300 \mu \mathrm{m}$ as compared a plate based on a particle size of $30 \mu \mathrm{m}$. The number of contact boundaries is much higher in plates based on smaller particles, and these contact boundaries restrict the conduction of heat.

With an increase in the NG particle size, both the bending strength and modulus of the composite plate decreases. The bending strength of a composite plate based on a particle size of $30 \mu \mathrm{m}$ made of NG, carbon black, chopped fiber and polymeric resin is 75 $\mathrm{MPa}$. In our earlier studies, it was found that a NG-resin composite plate made with $100 \mu \mathrm{m}$ particles results in a bending strength of 30 $35 \mathrm{MPa}$ [19]. Thus, the higher strength value is due to the strength imparted from the high-strength T-300 carbon fibers. Moreover, the accommodation of smaller carbon black particles between the NG particles increases the number of contact boundaries within the same composite volume. On the other hand, the bending strength of an EG-based composite plate is lower as compared to that of a NGbased plates, and with an increase in the particle size, the bending strength decreases, but these values satisfy the DOE target. Upon an addition of carbon fiber to a composite based on a $150 \mu \mathrm{m}$ particle size, the strength of bipolar plates increases with an increase in the fiber content. The increase in the strength is due to the fiber strength imparted by the EG-based composite plate.

Fig. 2 shows a SEM micrograph of carbon fiber incorporated in an EG-based composite plate. The individual fibers are dispersed between the EG particles. This helps to improve the load-bearing capacity of composite plates.

The thermal stability of both types of bipolar plates (NG- and EG-based) was measured by a thermogravimetric analysis in an air environment, showing that all of the plates are thermally stable at temperatures above $200^{\circ} \mathrm{C}$. A gas permeability test was also performed on all of the bipolar plate samples. It was found that all of the NG- and EG-based plates are impermeable to air, even at a pressure of $0.86 \mathrm{MPa}\left(8 \mathrm{Kg} \cdot \mathrm{cm}^{-2}\right)$.

Fig. 3 shows a comparison of the I-V performance levels of NG- and EG-based composite bipolar plates. The NG-based plate provides a maximum power density of $600 \mathrm{~mW} \cdot \mathrm{cm}^{-2}$ for a current density $1400 \mathrm{~mA} . \mathrm{cm}^{-2}$. However, the EG-based com-

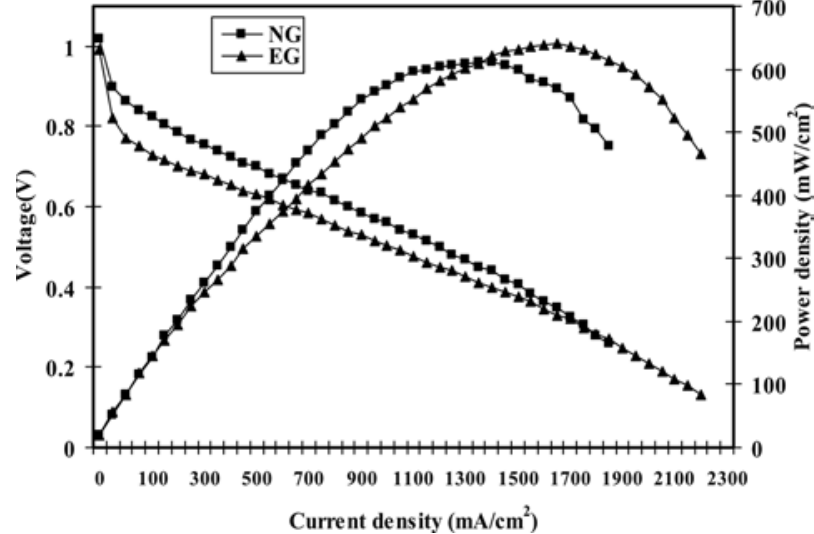

Fig. 3. I-V performance of NG- and EG-based composite bipolar plates in a unit fuel cell. NG: natural graphite, EG: expanded graphite.

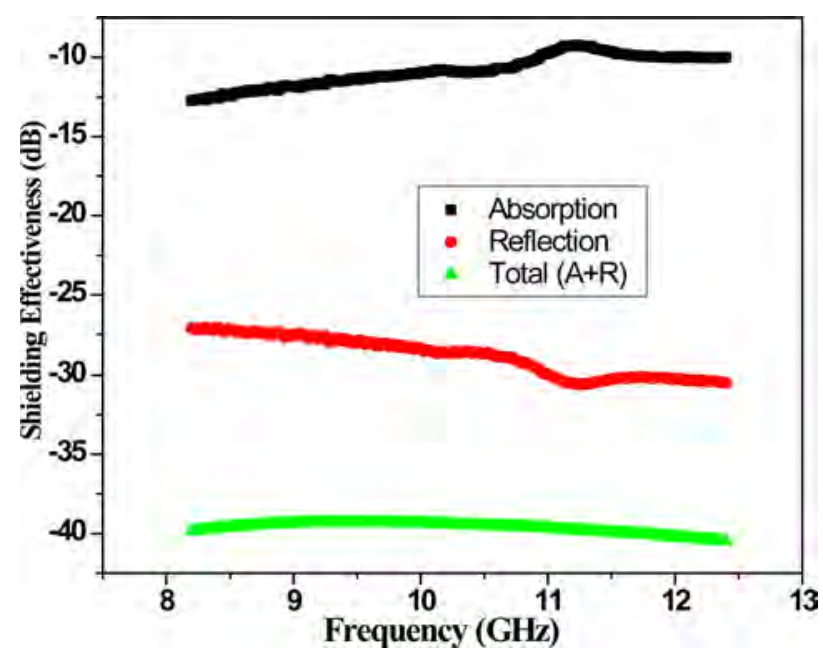

Fig. 4. Electromagnetic interference shielding effectiveness of an expanded graphite (EG)-based composite bipolar plate (30\% EG).

posite plate under identical conditions results in a power density that exceeds $600 \mathrm{~mW} \cdot \mathrm{cm}^{-2}$ for a current density $1600 \mathrm{~mA} \cdot \mathrm{cm}^{-2}$.

The I-V performance of a bipolar plate was measured three consecutive times in a unit fuel cell stack. It was found that there was little variation in the voltage and current density values during the first run and last run. Thus, the combination of a low density $\left(1.55 \mathrm{~g}_{\mathrm{cm}} \mathrm{cm}^{-3}\right)$ and a high EC for an EG-based bipolar plate can ultimately reduce the weight and volume of a fuel cell stack without compromising the performance.

Another application of a composite bipolar plate is as an EMI shielding material for electronic equipment to protect the equipment from electromagnetic radiation.

Fig. 4 shows the EMI shielding effectiveness of an EG-based composite bipolar plate with $30 \%$ EG. It provides electromagnetic shielding effectiveness of $40 \mathrm{~dB}$ in the $\mathrm{x}$-band frequency region $(8-12.4 \mathrm{GHz})$. The shielding effectiveness is mainly dominated by reflection $(27 \mathrm{~dB})$ due to the $\mathrm{EC}$ of the bipolar plates. Increasing the EG content further increases the shielding effectiveness to $65 \mathrm{~dB}$ with an EG content of $50 \%$. This shows that these bipolar plates can be utilized as EMI shielding materials to protect electronic equipment. 


\section{Conclusions}

It was observed that the particle size of a reinforcement material significantly influences the mechanical and electrical properties of composite bipolar plates. EG-based composite bipolar plates provide the desired mechanical and electrical properties as per the DOE targets with a bulk density of $1.55 \mathrm{~g} . \mathrm{cm}^{-3}$ as compared to 1.85 g. $\mathrm{cm}^{-3}$ for a NG-based plate. These plates are thermally stable at temperatures over $200^{\circ} \mathrm{C}$ and impermeable to air up to a pressure $8 \mathrm{Kg} \cdot \mathrm{cm}^{-2}$. An addition of carbon fiber to EG-based composites helps to improve the mechanical properties of a composite plate. However, due to the low conductivity of fiber, a decrease in the value of the conductivity of a composite plate arises, though the result nonetheless satisfies the DOE target for a bipolar plate. The I-V performance of an EG-based plate is slightly better than that of a NG plate, although the bulk density of the EG plate is $\sim 20 \%$ less than that of the NG plate. The modulus of an EG plate is less than that of a NG plate; this is attributed to the fact that EG-based plates are flexible, which can reduce the contact resistance between the components of a fuel cell stack, resulting in an improvement of the performance of the fuel cell. The EG bipolar plate can also be useful as an EMI shielding material.

\section{Acknowledgments}

The authors are very grateful to Prof. R.C. Budhani, Director of the NPL (CSIR), for his kind permission to publish the results.

\section{References}

[1] Joon K. Fuel cells: a 21st century power system. J Power Sources 71, 12 (1998). http://dx.doi.org/10.1016/S0378-7753(97)02765-1.

[2] Lemons RA. Fuel cells for transportation. J Power Sources, 29, 251 (1990). http://dx.doi.org/10.1016/0378-7753(90)80024-8.

[3] Tsuchiya H, Kobayashi O. Mass production cost of PEM fuel cell by learning curve. Int J Hydrogen Energy, 29, 985 (2004). http:// dx.doi.org/10.1016/j.ijhydene.2003.10.011.

[4] Larminie J, Dicks A. Fuel cell systems explained, Wiley, New York (2000).

[5] Makkus RC, Janssen AHH, de Brujin FA, Mallant RKAM. Stainless steel for cost-competitive bipolar plates in PEMFCs. Fuel Cell Bull, 3, 5 (2000). http://dx.doi.org/10.1016/S1464-2859(00)87319-8

[6] Wilson MS, Busick DN. Composites bipolar plate for electrochem- ical cells, WO00/25372, US Patent, 6,248,467 (2000).

[7] Dhakate SR, Sharma S, Borah M, Mathur RB, Dhami TL. Development and characterization of expanded graphite-based nanocomposite as bipolar plate for polymer electrolyte membrane fuel cells (PEMFCs). Energy Fuels, 22, 3329 (2008). http://dx.doi. org/10.1021/ef800135f.

[8] Dhakate SR, Mathur RB, Kakati BK, Dhami TL. Properties of graphite-composite bipolar plate prepared by compression molding technique for PEM fuel cell. Int J Hydrogen Energy, 32, 4537 (2007). http://dx.doi.org/10.1016/j.ijhydene.2007.02.017.

[9] Dhakate SR, Mathur RB, Sharma S, Borah M, Dhami TL. Influence of expanded graphite particle size on the properties of composite bipolar plates for fuel cell application. Energy Fuels, 23, 934 (2009). http://dx.doi.org/10.1021/ef800744m.

[10] Kuan HC, Ma CCM, Chen KH, Chen SM. Preparation, electrical, mechanical and thermal properties of composite bipolar plate for a fuel cell. J Power Sources, 134, 7 (2004). http://dx.doi.org/http:// dx.doi.org/10.1016/j.jpowsour.2004.02.024.

[11] Song LN, Xiao M, Meng YZ. Electrically conductive nanocomposites of aromatic polydisulfide/expanded graphite. Compos Sci Technol, 66, 2156 (2006). http://dx.doi.org/10.1016/j.compscitech. 2005.12.013.

[12] Heo SI, Oh KS, Yun JC, Jung SH, Yang YC, Han KS. Development of preform moulding technique using expanded graphite for proton exchange membrane fuel cell bipolar plates. J Power Sources, 171, 396 (2007). http://dx.doi.org/10.1016/j.jpowsour.2007.05.110.

[13] FuelCell Info.Com. Available from: http://www.fuelcell-info.com.

[14] SGL Group. Available from: http://www.sglcarbon.com/sgl_t/fuelcells/products/bma5.html.

[15] Lawrence RJ. Low cost bipolar current collector-separator for electrochemical cells. US Patent, 4,214,969 (1980).

[16] Huang J, Baird DG, McGrath JE. Development of fuel cell bipolar plates from graphite filled wet-lay thermoplastic composite materials. J Power Sources, 150, 110 (2005). http://dx.doi.org/10.1016/j. jpowsour.2005.02.074

[17] Hui C, Hong-bo L, Li Y, Jian-xin L, Li Y. Study on the preparation and properties of novolac epoxy/graphite composite bipolar plate for PEMFC. Int J Hydrogen Energy, 35, 3105 (2010). http://dx.doi. org/10.1016/j.ijhydene.2009.08.030.

[18] Wolf H, Willert-Porada M. Electrically conductive LCP-carbon composite with low carbon content for bipolar plate application in polymer electrolyte membrane fuel cell. J Power Sources, 153, 41 (2006). http://dx.doi.org/10.1016/j.jpowsour.2005.03.182.

[19] Mathur RB, Dhakate SR, Gupta DK, Dhami TL, Aggarwal RK. Effect of different carbon fillers on the properties of graphite composite bipolar plate. J Mater Process Technol, 203, 184 (2008). http:// dx.doi.org/10.1016/j.jmatprotec.2007.10.044. 